\title{
Inadvertent Perioperative Hypothermia: A Literature Review of an Old Overlooked Problem
}

\author{
Seyed Naser Lotfi Fatemi ${ }^{1}$, Mohammad Reza Armat ${ }^{1}$, Amir Emami Zeydi ${ }^{1}$, \\ Aria Soleimani², Farshad Hasanzadeh $\mathrm{Kiabi}^{2}$ \\ ${ }^{1} P h D$ candidate in Nursing, School of Nursing and Midwifery, \\ Mashhad University of Medical Sciences, Mashhad, Iran \\ ${ }^{2}$ Department of Anesthesiology, Faculty of Medicine, Mazandaran University of Medical Sciences, Sari, Iran
}

\begin{abstract}
SUMMARY
Inadvertent perioperative hypothermia is a common anesthesia-related complication in patients undergoing surgery. This could possibly lead to several clinical consequences, which adversely affect the surgery outcome, particularly in high risk patient. The combination of anesthetic drugs and cold operating room environment are among the most common predisposing factors of perioperative hypothermia. The aim of this comprehensive literature review is to describe the importance, monitoring techniques, potential complications, appropriate pharmacologic interventions and modalities to manage perioperative hypothermia.
\end{abstract}

Key words: perioperative hypothermia, thermoregulation, surgery, complication

Corresponding author:

Farshad Hasanzadeh Kiabi

e-mail: contactroute@yahoo.com 


\section{INTRODUCTION}

Inadvertent perioperative hypothermia $(\mathrm{PH})$ is defined as a body temperature lower than $36^{\circ} \mathrm{C}(1-3)$, and can be observed in $50 \%-90 \%$ of all the patients undergoing surgical procedures in operating room and postanesthetic care unit (PACU) (4-6). As PH potentially causes numerous adverse effects, its prevention may reduce associated morbidity, length of hospital stay, and healthcare costs (7).

Similar to many physiologic control systems, thermoregulation uses negative and positive feedback in the brain to minimize temperature perturbations (1, 2). Core body temperature is usually maintained near $37^{\circ} \mathrm{C}$ by thermoregulatory system. This homeostasis is achieved by vasoconstriction, vasodilatation, shivering, and sweating, as thermoregulatory defense mechanisms (8). Thermoregulation is usually impaired during general anesthesia (GA) (9). The severity of impairment is dose-dependant, frequently leading to $\mathrm{PH}$ in most surgical procedures, lasting more than 1 hour $(8,10)$.

Anesthetic-induced impairment of thermoregulation (AIIT) results in core-to-peripheral body heat redistribution that consequently leads to $\mathrm{PH}$. It means that the combination of AIIT and exposure to a cool environment of the operating theatre may cause hypothermia in most patients (11). The severity of hypothermia varies in different surgical procedures (12). PH usually occurs in three phases. During the first phase, a fast reduction in core temperature after anesthetic induction happens, mostly due to heat redistribution from core to the body surface. In the second phase, a slower reduction in the core temperature ensues (11). Finally, a core temperature plateau is reached, remaining constant till the end of surgery. The plateau happens passively, or results from the re-emergence of thermoregulatory mechanism in hypothermic patients (13).

The aim of this comprehensive literature review is to describe the importance, monitoring techniques, potential complications, the appropriate pharmacologic interventions and modalities to manage perioperative hypothermia.

\section{METHODS}

A search of the relevant literature was performed within international databases including Scopus,PubMed/Medline, Science Direct using the following search terms or their combinations: "hypothermia", "perioperative hypothermia", "thermoregulation", "anesthesia", "perioperative", "shivering", "temperature", "warming", "surgery", "operation" and "postoperative complication". These keywords were identified before initiating the search. A hand search of article references was done to ensure thoroughness of the search. Being limiting to the English language, without any time restriction, all articles containing the selected keywords in the title, abstract and text were included and evaluated.

\section{FINDINGS}

\section{Adverse effects of perioperative hypothermia}

$\mathrm{PH}$ may lead to some postoperative complications (14), including drug metabolism impairment, prolonged recovery from anesthesia, high plasma catecholamine concentration, cardiac morbidity, coagulopathy, impaired wound healing, wound infections, postoperative shivering, systemic and pulmonary vasoconstriction, increased arterial blood pressure, sympathetic hyperactivation, variations in serum potassium levels, impaired function of neutrophils and macrophages, and decreased partial oxygen pressure $(1,6,8,13,15-17)$.

Shivering, as a common complication of $\mathrm{PH}$, increases the total body oxygen consumption, due to the increase in the metabolic rate by $400 \%$ to $500 \%$, that could be detrimental to high risk patients (1). A study by Karalapillai et al. showed that after major elective noncardiac surgery, $46 \%$ of patients developed postoperative hypothermia. The transient hypothermia (temperature $<36^{\circ} \mathrm{C}$ corrected within $24 \mathrm{~h}$ ), and persistent hypothermia (hypothermia not corrected within 24h) were not associated with increased hospital mortality (5). The incidence of perioperative myocardial ischemia and dysrhythmia were more prevalent in hypothermic patients as compared to normothermic patients (18). Hypothermia could alter the enzymatic reactions velocity, coagulation cascade, and platelet function, thus increasing the demand for red-cell transfusion $(11,18)$.

It has been reported that mild hypothermia is associated with increased blood loss during surgery (11, 19). Also, it has been revealed that mild $\mathrm{PH}$ increased the risk of wound infection, as well as delaying wound healing (20). A study by Hasankhani et al. demonstrated that postoperative mean arterial blood pressure was 
significantly increased in the hypothermia group, as compared to normothermia group (17).

\section{Management of perioperative hypothermia}

Preserving perioperative normothermia is crucial for preventing inadvertent $\mathrm{HP}$, as well as its complications. This makes the patients feel more comfortable, increases their satisfaction, and decreases the patients' hospital stay in the $\operatorname{PACU}(1)$. The anesthesiology and surgical team (surgeons, preoperative nurses, circulating nurses, scrub persons, and PACU nurses) can use modalities to reduce hypothermia complications.

The American Society of Peri-Anesthesia Nurses introduced the first guideline for PH prevention (1). It provides direction for assessment and interventions during pre-, intra-, and postoperative phases. However, this guideline does not sufficiently provide pre-, and post-operative care. American Association of Nurse Anesthetists' guidelines recommend monitoring of body temperature during local, regional, and general surgical procedures. Similarly, the American Society of Anesthesiologists recommends constant evaluation of body temperature when clinically significant changes in body temperature are intended, anticipated, or suspected $(1,21)$. In patients undergoing major surgeries or GA longer than 30 minutes, the body temperature should be measured as a standard practice $(9,22)$.

Many different methods and sites are used to measure the body temperature perioperatively (23). Perioperative temperature monitoring devices vary by transducer type and the monitored site (15). Evidence shows that in noninvasive temperature monitoring, the oral route is the most reliable approach, but suffers from numerous limitations in the intraoperative phase. Infrared ear temperature measurement is inaccurate. Axillary route is the safest approach, and is helpful in patients who cannot have oral temperature readings. The accuracy and precision of axillary site is less than that of other sites. Intraoperatively, acceptable, lessinvasive temperature monitoring sites are the nasopharynx, esophagus, and urinary bladder (24). Monitoring of core temperature, among other vital signs, is advisable to detect temperature changes, thus preventing or correcting hypothermia (10). Constant intraoperative core temperature monitoring is recommended in all cases in which operations last longer than 30 minutes. The clinical setting, as well as the procedure used in surgery, determines how the core temperature should be monitored (25).
There are some methods to manage perioperative hypothermia $(\mathrm{PH})$ :

Passive insulation: Cotton blankets, surgical drapes, plastic sheeting, and reflective composites are available as the thermal insulators in most operating rooms (ORs). Having similar clinical benefits, these can reduce heat loss by approximately 30\% (11). Warmed cotton blankets do not affect core temperature and duration of hypothermia, whereas, they decrease radiation of heat. It is essential to keep the warming blanket dry, as the irrigation fluid may easily make it wet. Patients wearing warming gown are more likely to report normal body temperatures, and less likely to ask for additional blankets (13) .Heat loss through the skin can be reduced by passive insulation, but most patients need active warming to save normal temperature (26).

Pre-warmed intravenous (IV) fluids: Intraoperative administration of warm IV fluids may reduce $\mathrm{PH}$, postoperative shivering, and recovery time (17). The infusion of about $600-700 \mathrm{ml}$ of pre-warmed fluids $\left(41^{\circ} \mathrm{C}\right)$ may preserve perioperative normothermia, and decrease the incidence of postoperative shivering (3). Infusion of warm IV fluids, faster than one liter per hour, would be effective in such cases. Large volumes of fluids must be warmed to body temperature before infusion in order to avoid heat loss as well (27).

Forced-air warming: Evidence shows that patients who enter ORs with temperatures lower than $21^{\circ} \mathrm{C}$ became hypothermic (28); thus ORs need to be actively warmed. Use of forced-air warming, as one of several techniques to prevent inadvertent $\mathrm{PH}$, has been recommended for this purpose. Using this method to maintainthe temperature in normal ranges has been shown to be cost-effective and efficient. External warming enhances local blood flow, which in turn, increases oxygenation at cellular level. Moreover, warming may increase metabolism and cellular proliferation. Safe application of forced-air warming devices requires selection of the right device, following the manufacturer's recommendations, evaluation of patients' risks, and protecting them from burn injuries.

Pharmalogical management of shivering: Shivering sometimes needs pharmacologic treatment, including: pethidine, clonidine, and magnesium sulfate (9). Presence of pain and shivering in postoperative patients justifies the administration of opioids as the first choice in treating shivering. Among opioids, pharmacologic effect of pethidine is unique in increasing the shivering threshold (18). Shivering may be treated by IV administration of pethidine (50 mg within 5 minutes) in almost $90 \%$ of postoperative patients. However, 
pancuronium acts better than pethidine in treating postoperative shivering among patients undergone cardiac surgery, because it returns oxygen consumption to the baseline more efficiently. Given intravenously, clonidine as a centrally acting agent is effective in shivering. Premedication with oral clonidine produces less shivering in surgical patients (29). Moreover, there is evidence claiming that amino acid infusion during GA may stimulate energy expenditure as a useful and safe method in prevention of perioperative hypothermia (30). Also, it has been shown that ketamine, doxapram and meperidine have similar effect in preventing the postoperative shivering (27).

\section{DISCUSSION}

$\mathrm{PH}$ is a common complication of anesthesia. Evidence shows that perioperative hypothermia may increase the risk of infection, bleeding, and dysrhythmia, deserving more attention as a serious risk factor. According to previous studies, temperature should continuously be monitored perioperatively in major surgeries $(24,29)$. Forced air warming, as well as covers, may effectively reduce shivering and hypothermia risks, before, during, and after surgery (31).

Using warmed forced-air devices pre- and/or intra-operatively is efficient in minimizing the redistribution hypothermia following induction, whereas intraoperative usage of warmed IV fluids may help in reducing the risk of fluid-induced hypothermia, thereby improving normothermia(32). If the period of anaesthesia is longer than 60 minutes, active warming should be applied. Warming of irrigation fluids could be used as a complementary therapy (27).

In conclusion, perioperative hypothermia has been one of clinicians' concerns in the past decades worldwide. Although some influencing factors and their modalities have been discussed in the literature, reports show that it has not been sufficiently managed up to now, and healthcare systems still suffer from associated financial losses and clinical complications. It seems that future researches must answer the question why this problem still persists.

\section{References}

1. WEIRICH TL. Hypothermia/Warming Protocols: Why Are They Not Widely Used in the OR? AORN J. 2008;87:333-44.

2. Warttig S, Alderson P, Campbell G, Smith AF. Interventions for treating inadvertent postoperative hypothermia. Cochrane Database of Syst Rev 2014;11:CD009892.

3. Kim G, Kim MH, Lee SMet al. Effect of prewarmed intravenous fluids on perioperative hypothermia and shivering after ambulatory surgery under monitored anesthesia care. J Anesth 2014;28:880-5. http://dx.doi.org/10.1007/s00540-014-1820-z

4. Weyland W, Fritz U, Fabian Set al. Postoperative warming therapy in the recovery room. A comparison of radiative and convective warmers. Anaesthesist. 1994;42:648-57.

http://dx.doi.org/10.1007/s001010050105
5. Karalapillai D, Story D, Hart GKet al. Postoperative hypothermia and patient outcomes after major elective non-cardiac surgery. Anaesthesia. 2013; 68:605-11. http://dx.doi.org/10.1111/anae.12129

6. Rosenberg J, Sessler D. Mild intraoperative hypothermia. Another risk factor for postoperative complications. UgeskrLaeger. 1999;161:2935-8. (Article in Danish)

7. Waeschle R, Russo S, Sliwa Bet al. Perioperative thermal management in Germany varies depending on the hospital. Anaesthesist. 2015;64:612-22. (Article in German) http://dx.doi.org/10.1007/s00101-015-0057-z

8. Lenhardt R. The effect of anesthesia on body temperature control. Front Biosci (Schol Ed). 2010;1:1145-54.

http://dx.doi.org/10.2741/S123 
9. Sessler D. Temperature monitoring and perioperative thermoregulation. Anesthesiology. 2008;109:318-38.

http://dx.doi.org/10.1097/ALN.0b013e31817f6d76

10. Bustingorri JZ, Suárez JC. Non-therapeutic intraoperative hypothermia: prevention and treatment (part II). Rev EspAnestesiolReanim. 2003;50:197-208. (Article in Spanish)

11. Kurz A. Thermal care in the perioperative period. Best Pract Res ClinAnaesthesiol. 2008;22:39-62.

http://dx.doi.org/10.1016/j.bpa.2007.10.004

12. Vaughan M, Vaughan R, Cork R. Postoperative hypothermia in adults: relationship of age, anesthesia, and shivering to rewarming. AnesthAnalg. 1981;60:746-51. http://dx.doi.org/10.1213/00000539-19811000000010

13. Wasfie T, Barber K. Value of extended warming in patients undergoing elective surgery. IntSurg 2015;100:105-8.

http://dx.doi.org/10.9738/INTSURG-D-13-00155.1

14. Moola S, Lockwood C. Effectiveness of strategies for the management and/or prevention of hypothermia within the adult perioperative environment. Int J Evid Based Healthc. 2011;9:337-45.

http://dx.doi.org/10.1111/j.1744-1609.2011.00227.x

15. Insler S, Sessler D. Perioperative thermoregulation and temperature monitoring. AnesthesiolClin. 2006;24:823-37.

http://dx.doi.org/10.1016/j.atc.2006.09.001

16. Putzu M, Casati A, Berti Met al. Clinical complications, monitoring and management of perioperative mild hypothermia: anesthesiological features. Acta Biomed. 2007;78:163-9.

17. Hasankhani H, Mohammadi E, Moazzami Fet al.. The effects of intravenous fluids temperature on perioperative hemodynamic situation, postoperative shivering, and recovery in orthopaedic surgery. Can Oper Room Nurs J. 2007;25:20-4, 67.
18. Leslie K, Sessler DI. Perioperative hypothermia in the high-risk surgical patient. Best PractResClinAnaesthesiol. 2003;17:485 -98. http://dx.doi.org/10.1016/S1521-6896(03)00049-1

19. Winkler $\mathrm{M}, \mathrm{Akc}_{\mathrm{s}} \mathrm{a} \mathrm{O}$, Birkenberg B. Aggressive warming reduces blood loss during hip arthroplasty. AnesthAnalg. 2000;91:978-84. http://dx.doi.org/10.1097/00000539-20001000000039

20. Kurz A, Sessler D, Lenhardt R. Perioperative normothermia to reduce the incidence of surgical wound infection and shorten hospitalization. $\mathrm{N}$ Engl J Med. 1996;334:1209-15.

http://dx.doi.org/10.1056/NEJM199605093341901

21. WAGNER VD. Patient Safety Chiller: Unplanned Perioperative Hypothermia. PATIENT SAFETY FIRST. 2010;92:567-71. http://dx.doi.org/10.1016/j.aorn.2010.07.013

22. Singh A. Strategies for the management and avoidance of hypothermia in the perioperative environment. J PerioperPract. 2014;24:75-8.

23. Drake-Brockman T, Hegarty M, Chambers N, BS BvU-S. Monitoring temperature in children undergoing anaesthesia: a comparison of methods. Anaesth Intensive Care. 2014;42:315-20.

24. Torossian A. Thermal management during anaesthesia and thermoregulation standards for the prevention of inadvertent perioperative hypothermia. Best Pract Res ClinAnaesthesiol. 2008;22:659-68.

http://dx.doi.org/10.1016/j.bpa.2008.07.006

25. $\mathrm{Wu} X$. The safe and efficient use of forced-air warming systems. AORN J 2013;97:302-8. http://dx.doi.org/10.1016/j.aorn.2012.12.008

26. Horosz B, Malec-Milewska M. Methods to prevent intraoperative hypothermia. Anaesthesiol Intensive Ther. 2014;46:96-100. http://dx.doi.org/10.5603/AIT.2014.0019

27. HasannasabB, Banihashem N, Khoshbakht A. Prophylactic Effects of Doxapram, Ketamine and Meperidine in Postoperative Shivering.Anesth Pain Med 2016;6.1:e27515. http://dx.doi.org/10.5812/aapm.27515

28. Burns SM, Wojnakowski M, Piotrowski K, Caraffa G. Unintentional Hypothermia: 
Implications for Perianesthesia Nurses. JPerianesthNurs. 2009;24:167-76.

http://dx.doi.org/10.1016/j.jopan.2009.03.003

29. Forstot R. The etiology and management of inadvertent perioperative hypothermia. J ClinAnesth. 1995;7:657-74.

http://dx.doi.org/10.1213/00000539-19811000000010

30. Sellden E, Branstorm R, Brundin T. preoperative infusion of amino acids prevents posoperative hypothermia. BrJAnaesth. 1996:227-34. http://dx.doi.org/10.1093/bja/76.2.227
31. Munday J, Hines S, Chang A. Evidence utilisation project: Management of inadvertent perioperative hypothermia. The challenges of implementing best practice recommendations in the perioperative environment. Int J Evid Based Healthc. 2013;11:305-11.

http://dx.doi.org/10.1111/1744-1609.12035

32. Esnaola N, Cole D. Perioperative normothermia during major surgery: is it important? Adv Surg. 2011;45:249-63.

http://dx.doi.org/10.1016/j.yasu.2011.03.007 


\title{
Neželjena perioperativna hipotermija: pregled literature o starom problemu koje se često zanemaruje
}

\author{
Seyed Naser Lotfi Fatemi ${ }^{1}$, Mohammad Reza Armat ${ }^{1}$, Amir Emami Zeydi ${ }^{1}$, \\ Aria Soleimani², Farshad Hasanzadeh $\mathrm{Kiabi}^{2}$ \\ ${ }^{1}$ Student doktorskih studija iz oblasti bolničke nege, Departman za edukaciju medicinskih sestara, \\ sestrinstvo i akušerstvo, Univerzitet medicinskih nauka Mashhad, Mashhad, Iran \\ ${ }^{2}$ Departman za anesteziologiju, Medicinski fakultet, Univerzitet medicinskih nauka Mazandaran, Sari, Iran
}

\section{SAŽETAK}

Neplanirana perioperativna hipotermija je česta komplikacija u anesteziji tokom hirurških intervencija. Ona može da dovede do brojnih kliničkih posledica koje negativno utiču na ishod hirurških intervencija, naročito kod visoko rizičnih bolesnika. Kombinacija anestezioloških lekova i hladne operacione sale je među najčešćim predisponirajućim faktorima perioperativne hipotermije. Cilj ovog pregleda literature bio je da prikaže značaj, monitoring tehnike, potencijalne komplikacije, adekvatne farmakološke intervencije i načine za saniranje perioperativne hipotermije.

Ključne reči: perioperativna hipotermija, termoregulacija, hirurgija, komplikacija 